\title{
Relationship between parameters of public parks and their surroundings and the richness, diversity and species composition of vascular herbaceous plants on the example of Krakow in Central Europe
}

\begin{abstract}
Greenery is a natural value in urban space. To maintain the richness and diversity of greenery, it is necessary to understand the factors and mechanisms that influence vegetation. The purpose of this paper was to determine the impact of selected features of public parks and factors on the richness and diversity of herbaceous plants. In Krakow public parks, this richness and diversity is greater in parks with a larger area and habitat heterogeneity, the presence of migration corridors, and natural elements. Full stand coverage negatively affects diversity. Biologically inactive surface affects richness and diversity as well as a number of different groups of plant species. The presence of rare and nonsynanthropic species is related to the park's surface, natural elements, and its heterogeneity.
\end{abstract}

Łukasz Moszkowicz ${ }^{*}$, Izabela Krzeptowska-Moszkowicz ${ }^{1}$, Karolina Porada $^{1}$

1) Cracow University of Technology, Chair of Landscape Architecture, Krakow, Poland

*Corresponding author: Łukasz Moszkowicz, Cracow University of Technology, Chair of Landscape Architecture, Warszawska 24, 31-155 Krakow; Poland, Email: Imoszkowicz@pk.edu.pl

\section{Keywords:}

public park greenery, Krakow, species richness, species diversity, vascular plants, urban 


\section{Introduction}

Species richness and diversity are essential elements of natural value. Understanding the mechanisms influencing this richness and species composition is necessary to protect nature, which is strongly influenced by anthropogenic factors. Many authors note the influence of landscape use, its intensity and configuration on reducing biodiversity (e.g. Seppelt et al. 2016; Hallmann et al. 2017; Titeux et al 2018; Seibold et al. 2019). Many studies were devoted to factors influencing the formation of forest vegetation (e.g. Peterken 1996; Hermy et al. 1999; Dzwonko 1999; Butaye et al. 2001; Moszkowicz 2014) as well as semi-natural communities such as meadows, grasslands (e.g. Klimek et al. 2007; Szymura et al. 2016). Various authors pointed out the importance of the understory for the biodiversity of urban greenery (e.g. Threlfall et al. 2017). Studies indicate that some natural values may also constitute an herb layer of greenery elements in cities, e.g. public parks (Irvine et al. 2009; Carrus et al. 2015; Moszkowicz, Krzeptowska-Moszkowicz 2019). Factors that affect the richness and floristic pattern of the herb layer of parks in cities and surrounding landscape are less explored (e.g. Cornelis, Hermy 2004; Czortek, Pielech 2020). It is believed that the basic factors that affect the herb layer are the park's stand and treatments performed on it (LaPaix, Freedman 2010; Trzaskowska, Adamiec 2011; Fornal-Pieniak, Ollik 2013), herb layer care and its intensity (Fornal-Pieniak, Wysocki 2009) or a change in management (Bianco et al. 2003; DeCandido 2004). Vegetation richness is also determined by the degree of isolation from various elements of greenery and both natural, semi-natural, and synanthropic vegetation (e.g. McArthur and Wilson 1967; Dzwonko and Loster 1993; Jaccquemyn et al. 2001) and it could be depend on the location in the city (Ranta, Viljanen 2011; Moszkowicz, Krzeptowska-Moszkowicz 2020).

In addition, the park's herb layer is an element shaped mostly by natural factors, and the human capacity for creating species compositions is small. Therefore, plants of herb layer are suitable for studying the impact of ecological factors on the species composition of parks.
The purpose of this study was to determine the impact of selected parameters of parks and their surroundings that affect the richness, diversity and species composition of the herb layer of Krakow public parks.

Determining these relations is crucial to enhancing the state of the art by answering the question as to which of a park's parameters contribute to greater richness and diversity of vegetation, while also allowing to create guidelines for shaping certain park parameters.

Among the various parameters influencing the richness and diversity of vegetation, their area is one of the most crucial and was studied in detail by numerous authors, starting with MacArthur and Wilson (1967), and has recently been intensively discussed (e.g., Fahrig et al. 2019). The area parameter is the shape occupied by vegetation, which on a landscape scale has been indicated by various authors as an important factor for biodiversity (Moser et al. 2002, Saura, Carballal 2004, Flores et al. 2019), while in studies of the richness of plant communities it does not appear to be significant (Dzwonko, Loster 1992, Moszkowicz 2014). The parameter that various authors identify as having a positive effect on biodiversity is heterogeneity and topography (e.g., Stein, Kreft 2015). However, it has not been confirmed in urban greenery, which are public parks, whether their heterogeneity affects the richness of plants. It is believed that watercourses have a positive effect on the migration of organisms, including plants (e.g. Beier, Noss 1998; Czochański, Wiśniewski 2018). However, there is no data confirming whether the presence of a stream has a beneficial effect on a park's herb layer. There are also no studies on the impact of the age of a park and its origin on the richness and diversity of vascular plants, although some authors argued that in the case of forests these are important factors (e.g., Peterken 1996, Honnay et al. 1999, Orczewska 2009, Moszkowicz 2014).

The influence of the degree of urbanization of the environment on the richness and presence of various organisms is only partially recognized and discussed (e.g., Saari et al. 2016). On the other hand, the importance of the impact of migration corridors and isolation for the richness and diversity of organisms is widely confirmed in the literature (e.g. MacArthur, 
Wilson 1967; Hudgens, Haddad 2003; Couvreur et al. 2004). However, it is not known whether the significance of this parameter is the same for different groups of species, e.g., in the case of landscaped greenery. Various authors indicated a significant impact of the care and transformation of greenery on the shape and diversity of park vegetation (Bianco et al. 2003; LaPaix, Freedman 2010; Alsterberg 2017). It is known that mowing promotes the formation of certain groups of plant communities (e.g. Fornal-Pieniak, Wysocki 2009), but no direct confirmation whether there is a relationship between richness and diversity and the intensity of mowing has been found. It has also been demonstrated that the width of trails in parks influences the diversity and presence of alien species (LaPaix, Freedman 2010); The question is whether this is related to the share of biologically inactive elements? And whether the share of this type of surface affects the composition and species diversity of the herb layer. Does tree stand cover influence the shape of plant communities or does it influence the richness of vascular plants in public parks in a large city? It should be determined whether the presence of natural elements affects the richness and diversity of herb-layer plants in public parks, because this parameter is rarely discussed in studies, although, for example, LaPaix and Freedman (2010) showed the significance of forest remnants to native plants species growth in urban greenery.

\section{Methods}

\subsection{Study area}

Krakow is situated in the south part of Poland (Figure 1). The vegetation cover of the city is very diverse due to the location of the city at the interface of various geographical regions such as the Miechów Upland, the Krakowsko-Czestochowska Upland, the Carpathian Foothills, and the Sandomierska Valley with the Vistula River Valley (Wójcik 2007), and phytogeographic units, i.e., the Central European Lowland and Upland Province, and the Central European Mountain Province (Szafer 1972). There are about 100 plant communities in Krakow (Dubiel, Szwagrzyk 2008) and the flora of herbaceous vascular plants ex- cluding exotics exceeds 1300 species (Trzcińska-Tacik 1979). Numerous protected species are present here, as well as Natura 2000 priority habitats. Despite this significant floristic diversity, parks mostly occur in similar habitat conditions, usually in flat areas with anthropogenic soils. Most of them are subject to constant care and many other anthropogenic factors: vegetation isolation, intensive penetration by people and their pets, human recreational activity, pollution, city microclimate etc.

\subsection{Data collection}

Out of the greenery present in Krakow, 41 public parks were selected (Figure 1). The selection criteria were the like establish by Moszkowicz and Krzeptowska-Moszkowicz (2020): "The number of researched parks was limited [...], due to their functions, structure and composition, are public parks (e.g. Fudali, 2005). A part of various types of urban greenery referred to as parks are omitted because they are: narrow green lanes with the character of squares (e.g., Planty Dietlowskie Park, fragments of Vistula Boulevards); surroundings of forts (e.g. Batowice fort); areas occupied by natural and semi-natural vegetation, which are not characterized by a typical layout of public parks such as "Wolski Forest", "Witkowice Forest Park"; which are divided and not available for the public (e.g., Jalu Kurka Park)," (Moszkowicz, Krzeptowska-Moszkowicz 2020).

Herbaceous species of the herb layer were recorded in 2016 and 2017 in selected public parks. Each of the parks was searched at least three times from April to August to record the most complete list of herbaceous vascular plant species. Compositional elements such as rebates, flower beds, water reservoirs, and various plantings as well as so-called "flower meadows" that appeared in 2017 were omitted. This compositional element also contains foreign taxa, but due to the time of establishing "flower meadows" and the time of completion of the study, it was not possible to observe the penetration of these species into the park herb layer. During the study of the taxonomic composition of the herb layer, ornamental plants, tree seedlings and shrubs, and bush suckers were not taken into account, whereas native woody plants, such as Solanum dulcamara, were noted. 


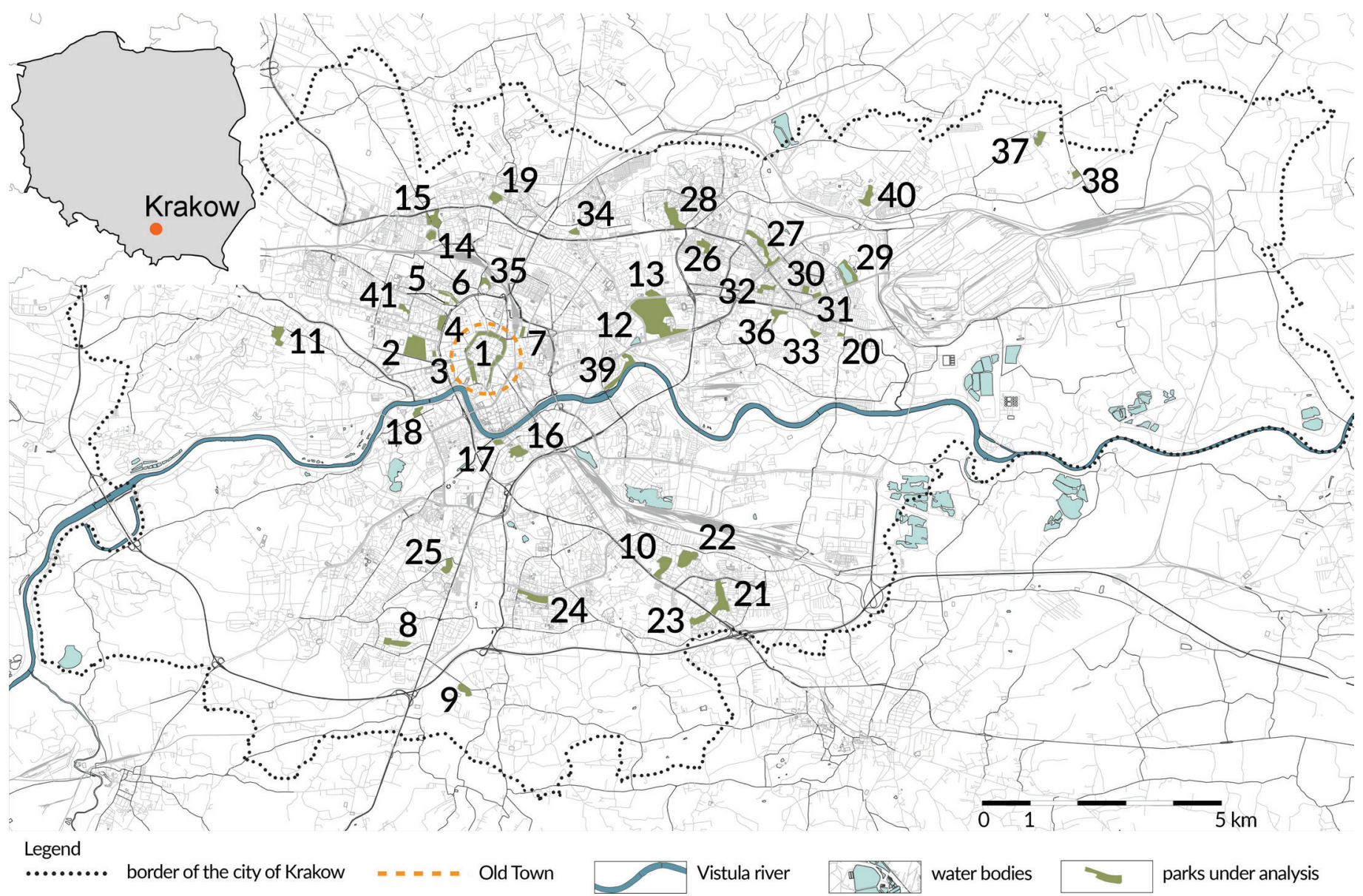

Figure 1. Distribution of the Krakow parks under study: 1.Krakow Plants, 2. Jordan Park, 3. Park nearby Jagiellonian Librery, 4. Krakowski Park, 5. Aksentowicz Park, 6. Młynówka Królewska Plants - east part, 7. Park Strzelecki, 8. Maćka i Doroty Park, 9. Zdrojowy Park in Swoszowice, 10. Jerzmanowskich Park, 11. Dębnicki Park, 12. Lotników Park - south part, 13. Lotników Park north part, 14. Wyspiańskiego Park, 15. Krowoderski Park, 16. Bednarski Park, 17. Nowacki Plants, 18. Decjusz Park, 19. Kościuszki Park, 20. Park nearby Willa Rogozińskich in Mogila, 21 Aleksandry Park - south part, 22. Lilii Wenedy Park, 23. Rżąska Park, 24. Kurdwanowski Park, 25. Solvay Park, 26. Dywizjonu 303 Park, 27. Bieńczyckie Plants south part, 28. Millenium Park, 29. Zalew Nowohucki Park, 30. Ratuszowy Park, 31. Szwedzki Park, 32. Wiśniowy Sad Park, 33. Żeromskiego Park, 34. Zaczarowanej Dorożki Park, 35. Kleparski Park, 36. Kultury Park, 37. Park in Łuczanowice, 38. Wadów Park, 39. Dąbie Park, 40. Zielony Jar Park, 41. Park of saint Wincent a'Paulo.

\subsection{Data analyses}

Based on the records obtained, the number of species, the number of represented families, the Simpson dominance index, the Shannon-Weaver diversity index (Shannon and Weaver 1963), the number of native non-synanthropic plants and that of synanthropic: apophytes, archeophytes, kenophytes (Zając, Zając 1992) were determined or calculated for each of the parks. Moreover, the following were identified: the number of species groups with different types of dissemination (Frank, Klotz 1988): anemochors, barochors, epizzochors, endozoochors, barochors, myrmecochors, as well as common and rare species in the flora of Poland and the Polish Red Book (Zarzycki, Mirek 2006), indicators of changes in flora following Chmiel (2006): synanthropization, apophytization, atropophytization, kenophytization, and modernization. Building multiple regression models with backward propagation using $\mathrm{F}$ input as 3 and $F$ removal equal to 2.95 (Sokal, Rolf 1996), the dependence of selected indicators, number, and shares of species groups on the parks and environment characteristics were calculated. Due to the relatively small sample (41 parks), separate regression models were built, taking into account three groups of park and environment features separately:

- surface topographic features: area, shape index, height (level) differentiation, water;

- historical features and park surroundings: age, origin, migration corridor, surrounding development; 
Table 1. Variables of parameters of parks and surroundings included in the regression analysis of the indicators of the richness and diversity of herb layer plants with explanation of variables.

\begin{tabular}{|l|c|c|c|c|}
\hline & Minimal & Maximal & Mean & Standard deviation \\
\hline Area (ha) & 0.5 & 37.27 & 7.037073 & 6.985167 \\
\hline Shape indicator & 1.08379 & 3.901894 & 1.602477 & 0.56149 \\
\hline
\end{tabular}

Shape indicator - calculated using the following formula: $I_{S}=P / 2 \sqrt{A \pi}$, where $\mathrm{P}$ denotes perimeter, and A denotes surface area;

\begin{tabular}{|c|c|c|c|c|}
\hline Terrain variation & 0 & 3 & 0.97561 & 0.907959 \\
\hline \multicolumn{5}{|c|}{ Terrain variation (level): 0 - flat, 1- slightly undulating, 2 - varied, 3 - large differences in elevation; } \\
\hline Presence of stream & 0 & 2 & 0.414634 & 0.706244 \\
\hline \multicolumn{5}{|c|}{ Presence of stream: 0 - no stream, 1 -small ditch , 2-stream; } \\
\hline Age of public park (years) & 13 & 482 & 99.46341 & 101.2048 \\
\hline \multicolumn{5}{|c|}{$\begin{array}{l}\text { The time elapsed between the area's establishment as a park and the completion of recording the composition, and other } \\
\text { vegetation parameters; }\end{array}$} \\
\hline Origin of the park & 1 & 6 & 3.95122 & 1.354644 \\
\hline \multicolumn{5}{|c|}{$\begin{array}{l}\text { Origin: the earlier character of the area where the park was established: } 1 \text { - walls, buildings, } 2 \text { - military areas, meadows, } 3 \\
\text { - urban greenery, gardens, fields, } 4 \text { - anthropogenic communities transformed by humans, } 5 \text { - meadows, other semi-natural } \\
\text { vegetation, } 6 \text { - natural vegetation; }\end{array}$} \\
\hline Surrounding urbanization & 1 & 4 & 2.317073 & 0.933783 \\
\hline \multicolumn{5}{|c|}{$\begin{array}{l}\text { Surrounding urbanization (landscape transformation). } 1 \text { - landscape built within industrial areas of block estates etc. withou } \\
\text { greenery, } 2 \text { - landscape built within industrial areas of block estates with current greenery, } 3 \text { - low-density development wit } \\
\text { current greenery, } 4 \text { - semi-natural or natural vegetation with low-density development; }\end{array}$} \\
\hline Migration corridor & 0 & 5 & 2.365854 & 1.684579 \\
\hline \multicolumn{5}{|c|}{$\begin{array}{l}\text { Parameters of the environment: ecological corridor, } 0 \text { - complete isolation, } 1 \text { - partial isolation at some distance, migration } \\
\text { corridors present, } 2 \text { - corridor of urban greenery, } 3 \text { - river, stream, } 4 \text { - a corridor with a river, a stream, and greenery, } 5-\text { a } \\
\text { corridor with natural and semi-natural vegetation; }\end{array}$} \\
\hline Mowing frequency & 0 & 4 & 3.073171 & 0.818237 \\
\hline \multicolumn{5}{|c|}{$\begin{array}{l}\text { Mowing frequency: } 0 \text { - not mowed, } 1 \text { - mowed once or twice a year, } 2 \text { - parts mowed several times a year, other times, } 3 \text { - } \\
\text { mowed several times a year, } 4 \text { - mowed during intensive vegetation at least once for two weeks; }\end{array}$} \\
\hline Natural elements in the park & 0 & 3 & 0.829268 & 1.138034 \\
\hline \multicolumn{5}{|c|}{ Unaltered areas present in the park 0 -none, 1 - only synanthropic, 2 -semi-natural, 3 -natural; } \\
\hline Share of biologically non active areas (\%) & 2 & 30 & 10.53659 & 5.792657 \\
\hline Tree stands cover (\%) & 5 & 90 & 64.70732 & 22.03434 \\
\hline
\end{tabular}

- park compositional parameters: the share of biologically inactive surfaces, park stand cover, mowing frequency, the presence of natural elements (Table 1.).

To avoid spatial autocorrelation, only partial regression coefficients with high statistical significance have been presented (Legendre, Legendre 2012). Additionally, cumulative values of the number of species together with its increase were compared with the cumulative values of the number of species together with the decrease of the areas of the parks to determine how the fragmentation of the parks affected their species richness (see Fahrig 2017).

\section{Results}

Regression analysis showed a strong impact of the park's areas as well as the presence of a migration corridor and natural elements in the park on the richness, diversity, and presence of various groups of herbaceous plants in the park's herb layer (Table 2 - Table 5).

Also, smaller fragmentation was observed not have a positive effect on the species richness of parks (Figure 2). 
Table 2. Indicators of the richness and diversity of herbaceous vascular species in the herb layer of Krakow parks.

\begin{tabular}{|l|c|c|c|c|}
\hline & Minimal & Maximal & Mean & Standard deviation \\
\hline Number of species & 14 & 137 & 55.2195122 & 20.60159241 \\
\hline Number of represented families & 14 & 34 & 23.73170732 & 4.837480699 \\
\hline Simpson dominance index & 0.00729927 & 0.071428571 & 0.021263528 & 0.011414336 \\
\hline Shannon-Weaver diversity index & -4.807012537 & -2.585840682 & -3.801913962 & 0.391292551 \\
\hline Simpson dominance of family index & 0.029411765 & 0.071428571 & 0.044009099 & 0.009753556 \\
\hline
\end{tabular}

The results also indicate that a higher proportion of biological inactive areas negatively affected the richness, diversity, and share of the non-synanthropic species present in the herb layer (table 3). The lower share of tree cover has a positive effect on the diversity and richness of the park. The origin of the park and the smaller transformation of the park's surroundings influence the greater share of native species in the herb layer.

The richness of herbaceous vascular plant species in the herb layer of Krakow parks and their diversity were found to depend primarily on the area, height differences, the presence of a migration corridor, and the presence of natural elements (Table 3 ). The richness and diversity were found to be negatively affected by large biologically inactive areas and the diversity specifically was adversely impacted by covering the entire park with trees. During the observation, a greater number of synanthropic species were recorded on non-forested or overexposed surfaces. Because these are the species dominating in numbers in the herb layer of Krakow parks, hence their diversity is associated with less tree cover.
Considering the types of species dissemination, the area had a positive effect on the number of rapidly and slow-spreading species (Table 4). The shape index favorably affected the share of slow-spreading species and negatively impacted the share of fast and far-spreading ones, which are usually anemochores. Less urbanized environments had a positive effect on the number of species that spread via animals. In turn, the number of species that spread in a different way is positively influenced by the migration corridor. Natural elements favorably affect the number of species both better and less spreading while the share of pavement has a negative effect.

The number and share of poorly spreading species such as myrmecochores and barochores are often associated with the presence of a migration corridor, shape index, and the presence of natural elements in the park (Table 4).

The variability in the number of rare and red-listed species is poorly explained by the examined factors (table 5). Undoubtedly, this is the result of their very rare presence in the herbs layer of individual parks. These groups are also related to natural elements

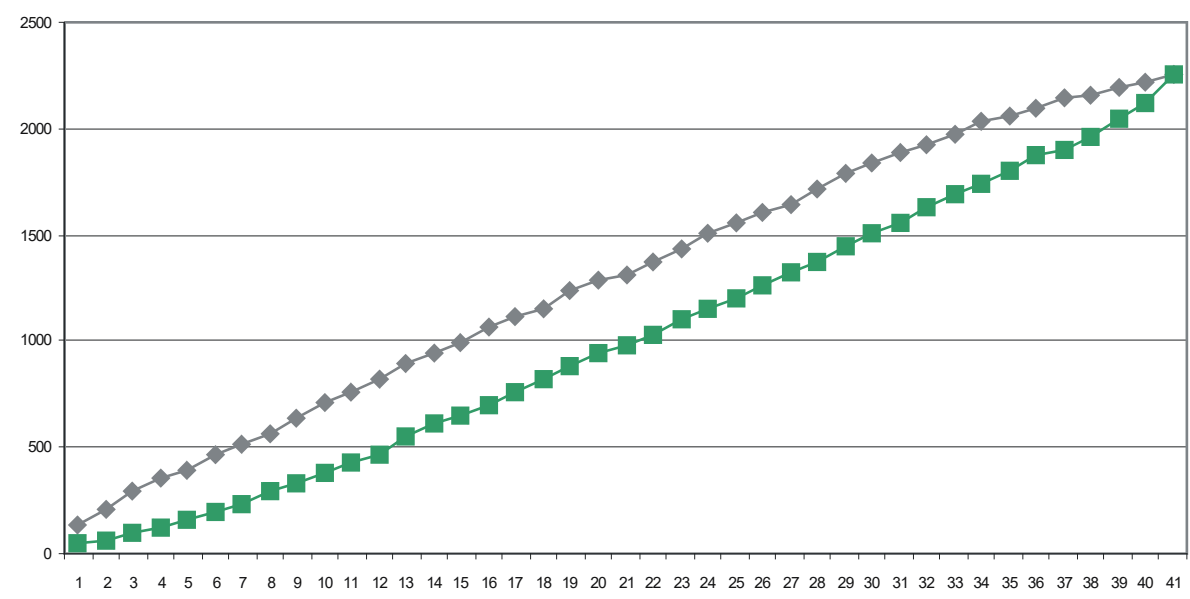

Figure 2. Cumulative values of the number of species in the herb layer of Krakow parks: grey diamonds in order of decreasing park area, green squares with an increasing area (see Fahrig 2017). X-axis: Order numbers of parks along with their increasing area; Y-axis: Cumulative number of species 
Table 3. Regression coefficients of richness and diversity indicators depending on selected park parameters in Krakow.

\begin{tabular}{|c|c|c|c|c|c|}
\hline & $\begin{array}{c}\text { Number of } \\
\text { species }\end{array}$ & $\begin{array}{l}\text { Number of } \\
\text { represented } \\
\text { families }\end{array}$ & $\begin{array}{c}\text { Shannon- } \\
\text { Weaver } \\
\text { diversity index }\end{array}$ & $\begin{array}{l}\text { Simpson } \\
\text { dominance } \\
\text { index }\end{array}$ & $\begin{array}{c}\text { Simpson } \\
\text { dominance } \\
\text { index of } \\
\text { families }\end{array}$ \\
\hline Area & $0.53 * * *$ & $0.36^{* *}$ & $0.50 * * *$ & $-0.57 * * *$ & \\
\hline \multicolumn{6}{|l|}{ Shape indicator } \\
\hline Terrain variation & $0.27^{*}$ & $0.42 * * *$ & $30 * *$ & & \\
\hline \multicolumn{6}{|l|}{ Presence of stream } \\
\hline $\mathrm{R}^{2}$ & 0.48 & 0.45 & 0.49 & 0.33 & \\
\hline Age of public park & & & & & $-0.41 * * *$ \\
\hline \multicolumn{6}{|l|}{ Origin of the park } \\
\hline \multicolumn{6}{|l|}{ Neighborhood } \\
\hline Migration corridor & $0.44 * * *$ & $0.60 * * *$ & $0.52 * * *$ & $-0.49 * * *$ & \\
\hline $\mathrm{R} 2$ & 0.20 & 0.36 & 0.28 & 0.24 & 0.17 \\
\hline Maintenance intensity & & $0.37^{*}$ & & & \\
\hline Natural elements in the park & $0.38 * *$ & $0.62 * * *$ & $0.29 * *$ & & \\
\hline Share of biologically non-active areas & $-0.43^{* *}$ & $-0.35 * *$ & $-0.59 * * *$ & $0.71 * * *$ & $-0.20 * *$ \\
\hline Tree stands cover & $-0.33^{*}$ & & $-0.39 * * *$ & $0.42 * * *$ & $-0.95^{* * *}$ \\
\hline $\mathrm{R}^{2}$ & 0.37 & 0.38 & 0.45 & 0.38 & 0.76 \\
\hline
\end{tabular}

Statistical significance level: $* 0.1>p>0.05 ; * * 0.05>p>0.01 ; * * p<0.01$

in the park, migration corridor, and surface. These factors also favor the presence of common and frequent species in the flora of parks. In turn, the number of rare species is also related to the age of the park, altitude level differences.

The share and number of the native non-synanthropic plants was found to be related to the heterogeneity of the terrain, i.e., height (level) differences, the presence of a stream (table 6). The age as well as the origin of the habitat or the nature of the surroundings, and the impact on native non-synanthropic species were also found to contribute. The presence of a migration corridor and migration elements was found to be very important for their occurrence. Their share was greater as there were few biologically inactive areas in the park. Non-synanthropic species were observed to depend on natural elements in the park, elements introducing heterogeneity, and park environment. The lack of connection between their share and migration corridor presence can be explained by the fact that these plants are very demanding in terms of habitat and the supply of diasporas does not change anything if there are no suitable conditions for their development.
It is also noticeable that the share of archaeophytes increases in the herb layer of isolated and flat parks. The presence of a migration corridor is also of little importance for the presence of kenophytes. Apophytes showed a very similar relationship to richness, perhaps because they constitute the dominant group of plants in the park herb layer.

\section{Discussion}

The importance of the area for richness and diversity was spread by the biogeography theory of the McArthur and Wilson islands (1967). This relationship has been confirmed by many studies (e.g. White et al. 1984; Jacquemyn, others 2001; Ma at al. 2002; Peintinger et al. 2003). Although this relationship is not always visible in specific spatial arrangements of communities (e.g. White et al. 1984; Moszkowicz 2014). In the following work, the favorable impact of the area was confirmed, the larger the, the richer it was in herbaceous vascular plant species, although this was also influenced by other factors. Cornelis and Hermy (2004) came to similar conclu- 
Table 4. Regression coefficients of spreading types depending on selected park parameters in Krakow.

\begin{tabular}{|c|c|c|c|c|c|c|c|c|c|c|c|}
\hline & $\begin{array}{l}\text { Share } \\
\text { of } \\
\text { anemo- } \\
\text { chores }\end{array}$ & $\begin{array}{l}\text { Num- } \\
\text { ber of } \\
\text { anemo- } \\
\text { chores }\end{array}$ & $\begin{array}{l}\text { Share of } \\
\text { auto- } \\
\text { chores }\end{array}$ & $\begin{array}{l}\text { Num- } \\
\text { ber of } \\
\text { auto- } \\
\text { chores }\end{array}$ & $\begin{array}{l}\text { Share } \\
\text { of baro- } \\
\text { chores }\end{array}$ & $\begin{array}{l}\text { Num- } \\
\text { ber of } \\
\text { baro- } \\
\text { chores }\end{array}$ & $\begin{array}{l}\text { Num- } \\
\text { ber of } \\
\text { endo- } \\
\text { zoo- } \\
\text { chores }\end{array}$ & $\begin{array}{c}\text { Share } \\
\text { of ep- } \\
\text { izoo- } \\
\text { chores }\end{array}$ & $\begin{array}{l}\text { Num- } \\
\text { ber of } \\
\text { epizoo- } \\
\text { chores }\end{array}$ & $\begin{array}{l}\text { Share } \\
\text { of myr- } \\
\text { meco- } \\
\text { chores }\end{array}$ & $\begin{array}{l}\text { Num- } \\
\text { ber of } \\
\text { myr- } \\
\text { meco- } \\
\text { chores }\end{array}$ \\
\hline Area & & $0.62^{* * *}$ & & $0.63^{* * *}$ & & $0.41^{* * *}$ & $0.45^{* * *}$ & & $0.46^{* * *}$ & & \\
\hline $\begin{array}{l}\text { Shape } \\
\text { indicator }\end{array}$ & $-0.41^{* *}$ & & & & $0.45^{* * *}$ & & & & & $0.51^{* * *}$ & \\
\hline $\begin{array}{l}\text { Terrain } \\
\text { variation }\end{array}$ & & & & & & & & & & & $0.58 * * *$ \\
\hline $\begin{array}{l}\text { Presence } \\
\text { of stream }\end{array}$ & & & & & & & & $0.40 * *$ & & & \\
\hline $\mathrm{R}^{2}$ & 0.17 & 0.38 & & 0.40 & 0.20 & 0.17 & 0.21 & 0.11 & 0.22 & 0.26 & 0.34 \\
\hline $\begin{array}{l}\text { Age of } \\
\text { public } \\
\text { park }\end{array}$ & & $-0.30 * *$ & $-0.38^{* *}$ & & & & & & & & \\
\hline $\begin{array}{l}\text { Origin of } \\
\text { the park }\end{array}$ & & & & & & $-0.33^{* *}$ & & $0.40 * *$ & & & \\
\hline $\begin{array}{l}\text { Neighbor- } \\
\text { hood }\end{array}$ & & & & & & & $0.37 * *$ & & $0.44 * * *$ & & \\
\hline $\begin{array}{l}\text { Migration } \\
\text { corridor }\end{array}$ & & $0.36^{* *}$ & & $0.51^{* * *}$ & & $0.60^{* * *}$ & & & & & $0.50 * * *$ \\
\hline $\mathrm{R}^{2}$ & & 0.19 & 0.15 & 0.26 & & 0.29 & 0.14 & 0.16 & 0.20 & & 0.25 \\
\hline \multicolumn{12}{|l|}{$\begin{array}{l}\text { Mainte- } \\
\text { nance } \\
\text { frequency }\end{array}$} \\
\hline $\begin{array}{l}\text { Natural el- } \\
\text { ements in } \\
\text { the park }\end{array}$ & & $0.28 *$ & & $0.38 * *$ & & $0.37 * *$ & $0.42 * * *$ & & $0.29 *$ & & $0.36 * *$ \\
\hline $\begin{array}{l}\text { Share of } \\
\text { biological- } \\
\text { ly non-ac- } \\
\text { tive areas }\end{array}$ & & $-0.42^{* *}$ & $-0.29 *$ & $0.69 * * *$ & & & & & $-0.41 * *$ & & $-0.33 * *$ \\
\hline $\begin{array}{l}\text { Tree } \\
\text { stands } \\
\text { cover }\end{array}$ & & $-0.37 * *$ & $-0.54 * * *$ & $-0.31 * *$ & & & & & $-0.40 * *$ & & \\
\hline $\mathrm{R}^{2}$ & & 0.28 & 0.23 & 0.43 & & 0.14 & 0.18 & & 0.29 & & 0.34 \\
\hline
\end{tabular}

Statistical significance level:*0.1>p>0.05;**0.05>p>0.01;***p<0.01

sions by studying parks in Flanders. The beneficial effect of fragmentation per se observed by various authors (e.g. Arroyo-Rodríguez et al. 2009; Ethier, Fahrig 2011) on richness was not observed here (Fig. 2). In the case of Krakow's parks, redevelopment has a negative influence on the richness and diversity of the herb layer (compare Fahrig 2017). Perhaps, one of the factors is that fragmentation is not conducive to heterogeneity, which is important to the diversity of organisms (Matlack 1994; Honnay et al. 1999) and on the contrary small parks are homogeneous.

Park location in the city area was found to be a factor that affects the biological richness and diversity, as indicated by some authors (Ranta, Viljanen 2011, Canedoli et al. 2018,). The vegetation of the herb layer of Krakow public parks shows an azonal character, which may be the result of the non-monocentric urban layout of the city. However, a link between species richness and diversity along with the distance 
Table 5.Regression coefficients for the number of species of groups with different frequency of occurrence in the Flora of Poland depending on selected park parameters in Krakow.

\begin{tabular}{|c|c|c|c|c|c|c|}
\hline & $\begin{array}{c}\text { Share of } \\
\text { common } \\
\text { species }\end{array}$ & $\begin{array}{c}\text { Number of } \\
\text { common } \\
\text { species }\end{array}$ & $\begin{array}{l}\text { Number } \\
\text { of often } \\
\text { species }\end{array}$ & $\begin{array}{c}\text { Number } \\
\text { of rare } \\
\text { species }\end{array}$ & $\begin{array}{l}\text { Share of } \\
\text { red-listed } \\
\text { species }\end{array}$ & $\begin{array}{c}\text { Number of } \\
\text { red-listed } \\
\text { species }\end{array}$ \\
\hline Area & $-0.45 * * *$ & $0.48 * * *$ & $0.60 * * *$ & & $0.36 * *$ & $0.42 * * *$ \\
\hline Shape indicator & & & & & & $0.24^{*}$ \\
\hline Terrain variation & & $0.29 * *$ & & $0.38 * *$ & & \\
\hline \multicolumn{7}{|l|}{ Presence of stream } \\
\hline $\mathrm{R}^{2}$ & 0.21 & 0.45 & 0.36 & 0.14 & 0.13 & 0.28 \\
\hline Age of public park & & & & $0.33 * *$ & & \\
\hline \multicolumn{7}{|l|}{ Origin of the park } \\
\hline Neighborhood & & & $0.41 * * *$ & & $-0.42 *$ & $-0.44 *$ \\
\hline Migration corridor & & $0.45 * * *$ & & & $0.57^{* *}$ & $0.61 * * *$ \\
\hline $\mathrm{R} 2$ & & 0.20 & 0.17 & 0.11 & 0.15 & 0.17 \\
\hline \multicolumn{7}{|l|}{ Maintenance intensity } \\
\hline Natural elements in the park & & $0.38 * * *$ & $0.36 * *$ & $0.32 * *$ & & $0.31^{* *}$ \\
\hline Share of biologically non-active areas & & $-0.45 * * *$ & & & & \\
\hline Tree stands cover & & $-0.36 * *$ & & & & \\
\hline $\mathrm{R}^{2}$ & & 0.40 & 0.13 & 0.10 & & 0.10 \\
\hline
\end{tabular}

Statistical significance level: ${ }^{*} 0.1>p>0.05 ; * * 0.05>p>0.01 ; * * p<0.01$

Table 6.Regression coefficients for the number of species of historical and geographical groups depending on selected park parameters in Krakow.

\begin{tabular}{|c|c|c|c|c|c|c|c|}
\hline & $\begin{array}{l}\text { Share of } \\
\text { nonsynan- } \\
\text { thropic }\end{array}$ & $\begin{array}{c}\text { Number of } \\
\text { nonsynan- } \\
\text { thropic }\end{array}$ & $\begin{array}{l}\text { Number of } \\
\text { apophytes }\end{array}$ & $\begin{array}{c}\text { Share of } \\
\text { archaeo- } \\
\text { phytes }\end{array}$ & $\begin{array}{c}\text { Number of } \\
\text { archaeo- } \\
\text { phytes }\end{array}$ & $\begin{array}{c}\text { Share } \\
\text { of keno- } \\
\text { phytes }\end{array}$ & $\begin{array}{c}\text { Number } \\
\text { of keno- } \\
\text { phytes }\end{array}$ \\
\hline Area & & $0.25^{*}$ & $0.51 * * *$ & & $0.36 * *$ & & $0.48 * * *$ \\
\hline \multicolumn{8}{|l|}{ Shape indicator } \\
\hline Terrain variation & $0.48 * * *$ & $0.49 * * *$ & $0.26 *$ & $-0.40 * * *$ & & & \\
\hline Presence of stream & $0.34^{* *}$ & & & & & $0.32 * *$ & $0.26 *$ \\
\hline $\mathrm{R}^{2}$ & 0.48 & 0.42 & 0.45 & 0.16 & 0.13 & 0.10 & 0.35 \\
\hline Age of public park & $0.28 * *$ & & & & & & \\
\hline Origin of the park & $0.29 * *$ & & & & & & \\
\hline Neighborhood & $0.33 * *$ & & & & & & \\
\hline Migration corridor & & $0.42 * * *$ & $0.46 * * *$ & $-0.51 * * *$ & & & $0.41^{* * *}$ \\
\hline $\mathrm{R} 2$ & 0.37 & 0.18 & 0.22 & 0.26 & & & 0.17 \\
\hline \multicolumn{8}{|l|}{ Maintenance intensity } \\
\hline Natural elements in the park & $0.55^{* * *}$ & $0.67^{* * *}$ & $0.38 * * *$ & $-0.47 * * *$ & & & $0.44 * * *$ \\
\hline $\begin{array}{l}\text { Share of biologically non-ac- } \\
\text { tive areas }\end{array}$ & $-0.29 * *$ & & $-0.47 * * *$ & $0.26^{*}$ & & & \\
\hline Tree stands cover & & & $-0.35^{* *}$ & & & & \\
\hline $\mathrm{R}^{2}$ & 0.51 & 0.45 & 0.42 & 0.38 & & & 0.19 \\
\hline
\end{tabular}

Statistical significance level: ${ }^{*} 0.1>p>0.05 ;{ }^{* *} 0.05>p>0.01 ; * * *<0.01$ 
of the park from the historic city centres is observed (Moszkowicz, Krzeptowska-Moszkowicz 2020).

The obvious relationship is the impact on the richness of migration corridors that enable the inflow of new and current species diasporas, contributing to the enrichment of genetic pools, or the renewed influx of species after their displacement from the parks (Beier, Noss 1998; Bennett 1999; Roy, de Blois 2008; Dallimer et al. 2012).

The impact of terrain diversity can be equated with increased exposition diversity and heterogeneity of habitats, just like the presence of a stream, hence its beneficial effect on richness and diversity. Some authors emphasize that the heterogeneity of microsites is the most decisive factor that conditions the richness of city parks (e.g. Nielsen et al. 2013). A park's heterogeneity is supported by diverted management of urban greenery (LaPaix, Freedman 2010; Alsterberg 2017).

The diversity and richness of the herb layer of Krakow parks are connected with the presence of natural elements, which coincides with Cornelis and Hermy's studies (2004). According to these authors, if the parks consist of semi-natural, they are rich in species. To support biodiversity, various authors suggest the naturalization of parks and the introduction of regionally native species, while pointing out that intensive management in parks simplifies the structure of vegetation and reduces the richness of plants (e.g. LaPaix, Freedman 2010). Many authors proved that the age of a woodland is a key factor for richness in plant forest species (e.g. Peterken 1996; Honnay et al. 1999; Dzwonko 2001; Moszkowicz 2014). In the case of the age of a park's establishment, no significant relationship was noted, probably because park continuity does not mean the continuity of the habitat and various transformations took place, including a change in the character of the park that could lead to species extinction (Bianco at al. 2003). At present, when the character of Krakow's public parks does not change, one can observe the effects of the following factors: soil replacement (with a layer of herb plants), setting up lawns and various other compositional elements in theplace of the herb layer, the creation of new surfaces, playgrounds, recreation equipment. Such actions may cause a decline of floristic richness and diversity. Some authors em- phasize that a change in land cover and land management is a factor that affects biodiversity (Savard et al.2000; Titeux et al. 2018).

LaPaix and Freedman (2010) indicate that the width trails in parks influence the surrounding vegetation, which is explained by the increased inflow of alien species and edge effects. They recommend supporting the biodiversity of the park areas by designing narrower roads and paths. These suggestions are consistent with the results obtained in this study, where the impact of the share of biologically inactive pavements, i.e., mainly communication trails, on the richness of herb layer plants is negative.

Considering the types of species dissemination, the area has a positive effect on those that spread quickly. This is in line with the observations of other authors (e.g. Jacquemyn et al. 2001). In contrast, the shape indicator is related with plants spread by animals, which is possibly associated with better penetration of the park with a larger perimeter, probably primarily birds can affect the influx of these species because their migration paths go beyond the green ecological corridors (Matlack 1996; Takahschi et al. 2004). The remaining groups of species show a greater number in the presence of migration corridors, which is confirmed by studies of other authors (e.g. Honnay et al. 2002; Roy, de Blois 2008).

Rare species are related to the surface area, the presence of a corridor, and the age of a park, which stands out in the context of other analyzes, but also coincides with what can be inferred from the literature. Rare and red-listed species in Poland are associated with natural elements in a park, which constitute their habitat (Zarzycki, Mirek 2006). The presence of other species for this category is related to the area. There are no optimal conditions for the development of these species and most of them come from places in the city, e.g., gardens where they are planted. Some researchers have observed unique plant species in urban forest areas, but only those that are not managed; the so-called wild (Müller et al. 2018). Native non-synanthropic species are an extremely rare element in the park herb layer, which is strongly influenced by human activity (LaPaix, Freedman 2010; Trzaskowska, Adamiec 2011; Fornal-Pieniak, Ollik 2013). 
The number and share of alien species (e.g. archaeophytes, kenophytes, diaphytes) did not show any connection with the urbanization of the surroundings. However, according to Kovarik's (1995) observations, their number decreases with distance from the city center. The negative impact of densely populated urban areas on biodiversity and beneficial on the number and abundance of alien species was also observed (Concepción et al. 2016). The relationship between the richness of herb plant species and distance from historic city centers was found by Moszkowicz and Krzeptowska (2020). The results of this study did not confirm the statistically significant influence of the surroundings on the richness and diversity of the herb layer except the influence on a group of species as zoochors. Czortek and Pielech (2020) found that less dense development supports the presence of woodland species. Other authors observed a decrease in the number of native species along with the intensification of urban traits of a city (Ranta, Viljanen 2011).

Czortek and Pielech (2020) observed that along with the densification of a river network, there is a greater number of kenophytes in city parks. The results of this study also showed that both the number and share of species of this group are favored by the presence of a park or the vicinity of a watercourse.

The analyzed factors and parameters of public parks also affect other groups of organisms, e.g. the connection of greenery has also a positive effect on the number of bird species (Huang et al. 2015). Müller and others (2018) also observed a relationship between wild greenery and the richness of other groups of organisms like birds and invertebrates, and broadly understood biodiversity.

On the other hand, the parameters of green vegetation, its richness, structure, and composition determine the richness and presence of other organisms. For example, Huang et al. (2015) demonstrated the influence of greenery in parks, the richness of herbaceous plants, woody plants, and the presence of corridors on the number of bird species and Müller et al. (2018) found a relation between herb richness and the number of invertebrates, mainly flower insects.

\section{Conclusions}

The variety and richness of a park's herb layer is an element of urban greenery's biodiversity. This element of vegetation is shaped less specifically and often less intensively than other green elements of public parks so the character of the herb layer is developed by both human influences and natural factors. The study of this part of vegetation in large city public parks in relation to various parameters of parks and their surroundings led to the following conclusions regarding their richness, diversity and composition:

The area of public parks and their heterogeneity associated with the diversity of the topography is of great importance for the species richness of plants, and no direct beneficial effect of fragmentation per se was observed. The homogeneity of public parks may favor the number of synanthropic species such as Archeophytes.

The study also showed that the shape of a park surface had no significant effect on the richness and diversity of the vascular plants of the herb layer, although its effect on other groups of organisms cannot be ruled out.

Streams in parks support the number of species that contribute to the value of plant cover, which are native non-synanthropic plants.

A lower degree of urbanization was observed to have a positive effect on the richness of zoochores; species whose dispersal efficiency is related to animals. It may be related to the greater number or diversity of animals in such areas, which has a positive effect on the process of migration and colonization of vascular plants in the parks.

Migration corridors are beneficial to species richness and diversity, although not all plant groups are essential. The presence of species spread thanks to birds are not significantly dependent on the migration corridors in a city, unlike other species.

No statistically significant influence of mowing on the richness and diversity of park herb layer plants in municipal public parks was observed. It probably depends on the character of the herb layer and species 
composition. However, freely growing, non-landscaped places in a park play were found to greatly contribute to the richness of herb vascular plants, but also are a refuge for native, non-synanthropic species; and even more so for rare and red-listed species.

Biologically inactive surfaces negatively affect the richness and diversity of herb layer as well as the number of different groups of plant species. This is only one of the reasons why park coverage with this type of surface should be limited.

Tree stand cover in an urban park dominated by synanthropic species negatively affected the diversity of the herb layer' vascular plants. In parks with forest undergrowth, tree cover may be either beneficial or irrelevant.

\section{References}

Alsterberg, C., Roger, F., Sundbäck, K., Juhanson, J., Hulth, S., Hallin, S., Gamfeldt, L., 2017. Habitat diversity and ecosystem multifunctionality-The importance of direct and indirect effects, Science Advances 3. DOI: 10.1126/sciadv.1601475.

Arroyo-Rodríguez, V., Pineda, E., Escobar, F., BenítezMalvido, J., 2009. Value of small patches in the conservation of plant-species diversity in highly fragmented rainforest, Conservation Biology 23, 729-739. DOI: 10.1111/j.15231739.2008.01120.x

Beier, P., Noss, R.F., 1998,. Do habitat corridors provide connectivity? Conservation Biology 12, 1241-1252. DOI: 10.1111/j.1523-1739.1998.

Bennett, A.F. Linkages in the landscape: the role of corridors and connectivity in wildlife conservation, IUCN, Gland, Switzerland, 1999. DOI: 10.2305/ IUCN.CH.2004.FR.1.en

Bianco, P.M., Fanelli, G., Tescarollo, P., Pignatti, S., 2003. Ruderalization in a Roman Parks as a Result of Changing Managemant, Urban Habitat 1, 87104.
Butaye, J., Jacquemyn, H., Hermy, M., 2001. Differential colonization causing non-random forest plant community structure in fragmented agricultural landscape. Ecography 24(4), 369380. DOI: 10.1111/j.1600-0587.2001.tb00472.x

Carrus, G., Scopelliti, M., Lafortezza, R., Colangelo, G., Ferrini, F., Salbitano, F., Agrimi, M., Portoghesi, L., Semenzato, P., Sanesi, G., 2015. Go greener, feel better? The positive effects of biodiversity on the well-being of individuals visiting urban and peri-urban green areas, Landscape and Urban Planning 134, 221-228. DOI: 10.1016/j. landurbplan.2014.10.022.

Chmiel, J., 2006. Zróżnicowanie przestrzenne flory jako podstawa ochrony przyrody w krajobrazie rolniczym (Spatial diversity of flora as the basis for nature protection in the agricultural landscape), Bogucki Wydawnictwa Naukowe, Poznań, 1-250.

Concepción, E.D., Obrist, M.K., Moretti, M., et al., 2016. Impacts of urban sprawl on species richness of plants, butterflies, gastropods and birds: not only built-up area matters, Urban Ecosystems 19, 225-242: DOI: 10.1007/s11252-015-0474-4

Cornelis, J., Hermy, M., 2004. Biodiversity relationships in urban and suburban parks in Flanders. Landscape and Urban Planning 69, 385401. DOI: 10.1016/j.landurbplan.2003.10.038

Couvreur, M., Christiaen, B., Verheyen, K., Hermy, M., 2004. Large herbivores as mobile links between isolated nature reserves through adhesive seed dispersal. Applied Vegetation Science, 7, 229-236. DOI: 10.1111/j.1654-109X.2004.tb00614.x

Czochański, J., Wiśniewski, P., 2018. River valleys as ecological corridors - structure, function and importance in the conservation of natural resources. Ecological Questions [online]:, 29, 1, 77-87. DOI: 10.12775/EQ.2018.006.

Czortek, P., Pielech, R., 2020. Surrounding landscape influences functional diversity of plant species in urban parks. Urban Forestry \& Urban Greening 47, 126525. DOI: 10.1016/j.ufug.2019.126525.

Dallimer, M., Rouquette, J.M., Skinner, A.M., Armsworth, P.R., Maltby, L.M., Warren, P.H., Gaston, K.J., 2012. Contrasting patterns in species 
richness of birds, butterflays and plants along riparian corridors in urban landscape, Diversity and Distributions 18(8). DOI: 10.1111/j.14724642.2012.00891.x

DeCandido, R., 2004. Recent changes in plant species diversity in urban Pelham Bay Park, 1947-1998, Biological Conservation 120, 129-136. DOI: 10.1016/j.biocon.2004.02.005

Dubiel, E., Szwagrzyk, J., 2008. Atlas roślinności rzeczywistej Krakowa (Atlas of vegetation of Krakow), Urząd Miasta Krakowa, Wydział Kształtowania Środowiska, Kraków, 7-52.

Dzwonko, Z., 2001. Migration of vascular plant species to a recent wood adjoining ancient woodland. Acta Societatis Botanicorum Polonica 70, 71-77. DOI: 10.5586/asbp.2001.010

Dzwonko, Z., Loster, S., 1993. Relations be-tween the floristic composition of isolated young woods and their proximity to ancient woodland, Journal of Vegetation Sciences 4, 693-698. DOI: $10.2307 / 3236135$

Dzwonko, Z., Loster, S., 1992. Species richness and seed dispersal to secondary woods in southern Poland. J. Biogeogr., 19: 195-204. DOI: $10.2307 / 2845505$

Ethier, K., Fahrig, L., 2011. Positive effects of forest fragmentation, independent of forest amount, on bat abundance in eastern Ontario, Canada, Landscape Ecology 26, 865-876. DOI: 10.1007/ s10980-011-9614-2

Fahrig, L., 2017. Ecological Responses to Habitat Fragmentation Per Se, Annual Review of Ecology Evolution, and Systematics 48, 1, 1-23. DOI: 10.1146/annurev-ecolsys-110316-022612

Fahrig, L., et al. 2019. Is habitat fragmentation bad for biodiversity? Biological Conservation 230 (2019) 179-186. DOI: 10.1016/j.biocon.2018.12.026

Flores, L. M. A., Zanette, L. R. S., Boscolo, D.; Araújo, F. S. 2019. Landscape Structure Effects on Bee and Wasp Assemblages in a Semiarid Buffer Zone. Landscape Online, 76, 1-17. DOI: 10.3097/ LO.201976
Fornal-Pieniak, B., Ollik, M., 2013. Diversity of flora in the undergrowth of park afforestations, rural plantings and oak-hornbeam forests. Folia Forestalia Polonica series A, 55(3), 132-136. DOI: 10.2478/ffp-2013-0014

Fornal-Pieniak, B., Wysocki, C., 2009. Przekształcenia szaty roślinnej parków wiejskich w Kotlinie Sandomierskiej. Acta Sci. Pol., Formatio Circumiectus, 8 (1-2), 27-34.

Fornal-Pieniak, B., Wysocki, C., 2009a. Zróżnicowanie florystyczno-fitosocjologiczne warstwy ziół parków Wiejskich w kotlinie sandomierskiej. Acta Sci. Pol., Formatio Circumiectus, 8(1-2), 3-12.

Frank, D., Klotz, S., 1988. Biologisch-Ökologische Daten zur Flora der DDR (Biological-ecological data on the flora of the GDR), Wissenschaftliche Beiträge der Martin-Luther-Universität HalleWittenberg, 1-168.

Hallmann, C.A., Sorg, M., Jongejans, E., Siepel, H., 2017. More than 75 percent decline over 27 years in total flying insect biomass in protected areas. PLOS ONE 12. DOI: 10.1371/journal. pone.0185809

Hermy, M., Honnay, O., Firbank, L., GrashofBodcam, C., Lawesson, J.E., 1999. An ecological comparison between ancient and other forest plant species of Europe and the implications for forest conservation. Biological Conservation 91, 9-22.

Honnay, O., Endels, P., Vereecken, H., Hermy, M., 1999. The role of patch area and habitat diversity in explaining native plant species richness in disturbed suburban forest patches in northern Belgium, Diversity and Distributions 5, 129-141. DOI: 10.1046/j.1472-4642.1999.00047.x

Honnay, O, Hermy, M, Coppin, P., 1999. Effects of area, age and diversity of forest patches in Belgium on plant species richness and implications for conservation and reforestation. Biol Conserv, 87(1), 73-84. DOI: 10.1016/S00063207(98)00038-X

Honnay, O., Verheyen, K., Butaye, J., Jacquemyn, H., Bossuyt, B., Hermy, M., 2002. Possible effects of habitat fragmentation and climate change 
on the range of forest plant species, Ecology Letters 5(4), 525-530. DOI: 10.1046/j.14610248.2002.00346.x

Hudgens, B., Haddad N., 2003. Predicting which species will benefit from corridors in fragmented landscapes from population growth models. The American Naturalist, 161:5, 808-820. DOI: $10.1086 / 374343$

Irvine, K., Fuller, R., Devine-Wright, P., Tratalos, J., Payne, S., Warren, P., Lomas, K., Gaston, K., 2010. Ecological and Psychological Value of Urban Green Space. In: Jenks, M., Jones, C. (eds) Dimensions of the Sustainable City. Future City, Springer, Dordrecht, Netherlands, vol 2. DOI: 10.1007/9781-4020-8647-2_10

Jacquemyn, H., Butaye, J., Dumortier, M., Hermy, M., Lust, N., 2001. Effects of age and distance on the composition of mixed decidous forest fragments in an agricultural landscape, Journal of Vegetation Sciences 12, 635-642. DOI: 10.2307/3236903

Jacquemyn, H., Butaye, J., Hermy, M., 2001. Forest plant species richness in small fragmented mixed deciduous forest patches: the role of area, time and dispersal limitation, Journal of Biogeography 28, (6), 801-812. DOI: 10.1046/j.13652699.2001.00590.x

Klimek, S., Hofmann, M., Isselstein, J., 2007. Plant species richness and composition in managed grasslands the relative importance of field management and enviromental factors. Biological Conservation 134, (4), 559-570. DOI: 10.1016/j. biocon.2006.09.007

Kowarik, I., 1990. Some responses of flora and vegetation to urbanization in central Europe. In: Sukopp, H., Hejny, S., Kowarik, I. (eds.), Urban ecology: plants and plant communities in urban environments, SPB Academic Publishing, Amsterdam, 45-74.

Kowarik, I., 1995. On the role of alien species in urban flora and vegetation. In Pysek, P., Prach, K., Rejmánek, M., Wade, PM. (eds) Plant InvasionsGeneral Aspects and Special Problems, SPB Academic, Amsterdam (Netherlands), 85-103.
LaPaix, R., Freedman, B., 2010. Vegetation Structure and Composition within Urban Parks of Halifax Regional Municipality, Nova Scotia, Canada. Landscape and Urban Planning 98, 124-135. DOI: 10.1016/j.landurbplan.2010.07.019.

Legendre, P., Legendre, L., 2012. Numerical Ecology 24, 3rd edition, 1-1006

Ma, M., Tarmi, S., Helenius, J., 2002. Revisiting the species-area relationship in a semi-natural habitat: floral richness in agricultural buffer zones in Finland, Agriculture, Ecosystems \& Environment 89, (1-2), 137-148. DOI: 10.1016/ S0167-8809(01)00325-5.

Matlack, G., 1994. Plant species migration in mixedhistory forest landscape in eastern North America, Ecology 75, 1491-1502.

McArthur, R., Wilson, E., 1967. The theory of island biogeography. Princeton University Press, Princeton, New Jersey, 1-203.

Mirek, Z., Zarzycki, K., Wojewoda, W., Szeląg, Z., 2006. Red list of plants and fungi in Poland, $W$. Szafer Institute of Botany, Polish Academy of Sciences, Kraków.

Moser, D., Zechmeister, H.G., Plutzar, C., Sauberer, N., Wrbka, T., Grabherr, G., 2002. Landscape patch shape complexity as an effective measure for plant species richness in rural landscapes. Landscape Ecol, 17(7), 657-669. DOI: 10.1023/A:1021513729205

Moszkowicz, Ł., 2014. Relationship between plant species richness and age of woodland patches (Ojców National Park, Poland). Polish Journal of Ecology 62, (4), 649-664. DOI: $10.3161 / 104.062 .0410$

Moszkowicz, Ł., Krzeptowska-Moszkowicz, I., 2019. The richness of herbaceous vascular plant of Krakow public parks. Kraków: 58 Meeting of Polish Society of Botany, Kraków, 3-7 July 104.

Moszkowicz, Ł., Krzeptowska-Moszkowicz, I., 2020. Impact of the public parks location in the city on the richness and diversity of herbaceous vascular plants on the example of Krakow Southern Poland, Plants in Urban areas and Landscape 98103. DOI: 10.15414/PUAL/2020.98-103. 
Müller, A., Bøchera, P., Fischerc, C., Svenning, J., 2018. 'Wild' in the city context: Do relative wild areas offer opportunities for urban biodiversity? Landscape and Urban Planning 170, 256-265. DOI: 10.1016/j.landurbplan.2017.09.027.

Nielsen A., Van den Bosch, M., Maruthaveeran, S., Van den Bosch, C., 2013. Species richness in urban parks and its drivers: A review of empirical evidence, Urban Ecosystems 17(1). DOI: 10.1007/ s11252-013-0316-1

Orczewska, A., 2009. Age and origin of forests in southwestern Poland and their importance for ecological studies in man-dominated landscapes. Landsc Res., 34(5),599-617. DOI: 10.1080/01426390903223153

Peintinger, M., Bergamini, A., Schmid, B., 2003. Species-area relationships and nestedness of four taxonomic groups in fragmented wetlands, Basic and Applied Ecology 4(5), 385-394. DOI: 10.1078/1439-1791-00181.

Peterken, G., 1996. Natural woodland. Ecology and conservation in northern temperate regions. Cambridge, Cambridge University Press, Great Britain, part 1-3, 1-297.

Ranta, P., Viljanen, V., 2011. Vascular plants along an urban-rural gradient in the city of Tampere, Finland, Urban Ecosystem 14, 361-376. DOI: 10.1007/s11252-011-0164-9

Roy, V., de Blois, S., 2008. Evaluating hedgerow corridors for the conservation of native forest herb diversity, Biological Conservation 141, 298307. DOI: 10.1016/j.biocon.2007.10.003

Saari, S., Higgins, M., Richter, S., Faeth, S., 2016. Urbanization is not associated with increased abundance or decreased richness of terrestrial animals - dissecting the literature through metaanalysis. Urban Ecosystems, 19(3), 1251-1264. DOI: $10.1007 / \mathrm{s} 11252-016-0549-x$

Saura, S., Carballal, P., 2004. Discrimination of native and exotic forest patterns through shape irregularity indices: an analysis in the landscapes of Galicia, Spain. Landscape Ecol, 19(6), 647-662. DOI: 10.1023/B:LAND.0000042905.97437.78
Savard, J-P., Clergeau, P., Mennechez, G., 2000. Biodiversity concepts and urban ecosystems, Landscape and Urban Planning 48 (3-4), 131-142. DOI: 10.1016/S0169-2046 (00)00037-2.

Seibold, S., Gossner, M.M., Simons, N.K. et al., 2019. Arthropod decline in grasslands and forests is associated with landscape-level drivers. Nature 574, 671-674. DOI: 10.1038/s41586-019-1684-3

Seppelt, R., Beckmann, M., Ceauşu, S., Cord, A., Gerstner, K., Gurevitch, J., et al., 2016. Harmonizing Biodiversity Conservation and Productivity in the Context of Increasing Demands on Landscapes, BioScience 66(10), 890-896. DOI: 10.1093/biosci/ biw004

Shannon, C., Weaver, W., 1963. The mathematical theory of communication, University of Illinois Press, Urbana-Champaign, Illinois, 1-117.

Sokal, R., Rohlf, F., 1998. Biometry: the principles and practice of statistics in biological research, W.H. Freeman and Company, New York, 1-880.

Szafer, W., Zarzycki, K., 1972. Szata roślinna Polski, PWN, Warszawa, 1- 678.

Szymura, M., Szymura, T., Dradach, A., Mikołajczak, Z., 2016. Biodiversity of grasslands of Stołowe Mountains National Park. Acta Scientarum Polonica Agricultura 15, (1), 69-82.

Takahashi, K., Kamitani, T., 2004. Effect of dispersal capacity on forest plant migration at landscape scale. Journal of Ecology 92, (5), 778-785. DOI: 10.1111/j.0022-0477.2004.00927.x

Threlfall, C., Mata, L., Mackie, J., Hahs, A., Stork, N., Williams, N., Livesley, S., 2017. Increasing biodiversity in urban green spaces through simple vegetation interventions. Journal of Applied Ecology 54(6):1874-1883. DOI: 10.1111/13652664.12876

Titeux, N., Henle, K., Mihoub, J., Regos, A., Geijzendorffer, I., Cramer, W., Verburg, P., Brotons, L., 2018. Biodiversity scenarios neglect future land-use changes. Global Change Biology 22(7), 2505-2515. DOI: 10.1111/gcb.13272 
Trzaskowska, E., Adamiec, P., 2011. Runo parków miejskich Lublina, Acta Scientarum Polonica Formatio Circumiectus, 10(4), 51-59.

Trzcińska-Tacik, H., 1979. Flora synantropijna Krakowa (Synanthropic flora of Krakow), Zeszyty Naukowe UJ, Rozprawy habilitacyjne, Kraków, 32, 1-249.

White, P., Miller, R., Ramseur, G., 1984. The SpeciesArea Relationship of the Southern Appalachian High Peaks. Vascular Plant Richness and Rare Plant Distributions, Castanea 49(2), 47-61. URL: www.jstor.org/stable/4033264

Wójcik, A., 2007. Budowa geologiczna (Geological structure). In: Jędrychowski, I. (Eds), Atlas Kampusu 600-lecia odnowienia Uniwersytetu Jagiellońskiego (Campus Atlas 600 years of renewal of the Jagiellonian University), Instytut Geografi i i Gospodarki Przestrzennej UJ 28, Kraków, 28-29.

Zając, A., Zając, M., 1992. Tentative list of segetal and ruderal apophytes in Poland. Botanical Papers 24, 7-23. 